\title{
Differing Fine-Scale Responses of Vegetation and Bare Soil to Moisture Variation in a Pinyon-Juniper Woodland Underlie Landscape-Scale Responses Observed from Remote Sensing
}

\author{
D. A. Devitt ${ }^{1}$ B. Bird ${ }^{1}$, L. Fenstermaker ${ }^{2} \&$ M. D. Petrie ${ }^{1}$ \\ ${ }^{1}$ School of Life Sciences, University of Nevada Las Vegas, Las Vegas, NV \\ ${ }^{2}$ Desert Research Institute, Las Vegas, NV \\ Correspondence: D. A. Devitt, School of Life Sciences, University of Nevada Las Vegas, Las Vegas, NV. E-mail: \\ dale.devitt@unlv.edu
}

Received: March 20, 2021

Accepted: April 2, $2021 \quad$ Online Published: June 30, 2021

doi:10.5539/enrr.v11n1p1

URL: https://doi.org/10.5539/enrr.v11n1p1

\begin{abstract}
Pinyon juniper woodlands in the American southwest face an uncertain ecological future with regard to climate altered precipitation. Although satellite remote sensing will be relied upon to assess the overall health of these plant communities more fine scaled information is needed to elucidate the mechanisms shaping the broader scaled regional assessments. We conducted a study to assess the NDVI response at the plant canopy level (insitu sensors placed over the canopies) of three tree and one shrub species to changes in precipitation, reference evapotranspiration and soil volumetric water content. Landsat data was used to compare stand integrated and satellite NDVI values. We also provided supplemental water in the amount of $10.85 \mathrm{~cm}$ over the study period to additional trees and shrubs which also had insitu NDVI sensors placed over their canopies. NDVI at the canopy level separated statistically by species and when contrasted with bare soil $(p<0.001)$. Spring early summer dry down events were inversely related to increasing ETref-precipitation with a steeper dry down slope in the first year associated with no rainfall occurring in May and June. All three-tree species did not show any significant difference in canopy NDVI based on supplemental water, however the shrub species did reveal a significant response to water $(\mathrm{p}<0.001)$. Although all of the three-tree species revealed a one-month period in which they responded to precipitation in July of the first year after $11.2 \mathrm{~cm}$ of precipitation, no immediate (day of or next day) response was observed to precipitation or supplemental water events. Snowberry was unique in its NDVI response during the spring green up period in the second year revealing a highly linear shift over a 40-day period with a clear separation between treatments $(\mathrm{p}<0.001)$ with those plants receiving supplemental water having a higher more positive slope. Landsat NDVI values revealed an inverse sinusoidal relationship with ETref-precipitation $\left(R^{2}=0.59\right.$ $\mathrm{p}=0.012)$. Landsat values $(0.19+/-0.01)$ were found to have no significant difference with bare soil NDVI $(0.17+/-$ 0.01 ) but were significantly different from all four tree and shrub species. Integrated NDVI based on sensor weighted \% cover estimates $(0.37+/-0.03)$ were nearly double Landsat values $(0.19+/-0.01)$. Both NDVI values of pinyon pine and Utah juniper were found to be linear correlated with Landsat NDVI in the second Year $\left(R^{2}>0.75\right.$, $\mathrm{p}<0.001)$. Multiple regression analysis revealed that $95 \%$ of the variation in Landsat NDVI in the second year could be accounted for based on bare soil NDVI and pinyon pine NDVI ( $\mathrm{p}<0.001)$. et al., NDVI interspace (bare soil) of pinyon juniper woodlands dominated the nature of the Landsat curve. Our results demonstrate the value of ground sensors to help fill the gap between what can be inferred at the forest canopy level and what is occurring at the plant level.
\end{abstract}

Keywords: NDVI, Supplemental Water, Environmental Demand, Plant Water Status

\section{Introduction}

Precipitation-derived soil moisture is one of the most important drivers of vegetation growth and productivity in semiarid ecosystems (Rodriguez-Iturbe, 2000), and temporal variation in soil moisture on the order of multiple days to multiple years exerts a strong control on vegetation dynamics at the plant and community stand level (Rasmussen et al., 2014; Bell et al., 2010). Although climate models predict that warming temperatures and declining precipitation will drive water deficits and overall aridity in semiarid ecoregions in coming decades (Nogues Bravo et al., 2007; Clow, 2009; IPCC, 2013; Jones \& Gutzler, 2016), the role of precipitation change on 
future trends in ecosystem water balance and aridity is more uncertain across the American southwest (IPCC 2014; Barnes et al., 2016; Bradford et al., 2020), which portends to similarly uncertain regional ecological futures. Although challenges associated with resolving the drivers of et al., and forecasting regional precipitation and water balance patterns is one important component of future ecological uncertainty (Wuebbles et al., 2017), how precipitation and water balance variation will be realized at et al., finer local scales is equally important from an ecological standpoint because these are the scales over which influential land surface factors including topography, soil properties and vegetation characteristics are most heterogeneous (Mulla, 2012). Indeed, although the goal of robust sub-regional meteorological forecasts of climate and water balance is of high importance, efforts to forecast ecological futures at the finer scales of species, communities and ecological landscapes will also be important.

Precipitation may increase in some regions and decrease in others (Seager et al., 2007), or precipitation may simply become more variable, including higher intensity storms (Trenberth et al., 2003; Karl 2009). In southern Nevada, precipitation can also be significantly influenced by the extent that monsoonal conditions move into the region (Truettner et al., 2019), typically during the months of July and August but also by the influence of El Nino and La Nina years that can significantly alter the dynamic interaction of soils, plants and water (Scanlon et al., 2005; Bunting et al., 2017).

An important aspect of elucidating potential ecosystem futures is linking fine-scale, detailed information from field measurements and experiments to the less detailed and often broader scale information provided by climate forecasts and computational models. et al., Remotely-sensed vegetation indices have been used successfully as an intermediate information source to better link fine and broad-scale information. These indices characterize the scope and scale of local (Weisberg, 2007) and regional (Breshears, 2005) patterns and responses of ecosystems, yet more detailed, often field-based, analyses are required to elucidate the mechanisms shaping them (Breshears, 2009; Flake \& Weisberg, 2019). The resolution of satellite data may not be high enough to enable the detection of changes at the plant level (Baghzouz et al., 2010) that are signaling the onset of stress, especially in multi-species plant communities with lower percent cover that possess understory vegetation with greater bare soil exposure (Snyder et al., 2019).Recent work by Allred (2020) has focused on the influence of fine-scale heterogeneous vegetation cover and vegetation responses in satellite imagery, more work is needed linking fine- and intermediate-scale information across a broad range of ecosystems as a critical component of understanding species and ecological futures.

Remotely sensing the spectral reflectance of vegetation provides a unique opportunity to monitor dynamic changes in forest canopies brought about by environmental change (Pettorelli et al., 2005) as specific wavelengths are being identified that elucidate species responses to the environment and stress. These indices are also useful because they can be measured by both ground-based and satellite-based instruments providing a direct link between observed responses at different spatial and temporal scales. NDVI in particular is a vegetation index that has been demonstrated to be an excellent tool for assessing plant phenology (Baghzouz et al, 2010; Wolkovich et al., 2012; Reed et al., 2019), soil moisture (Wang et al., 2003), soil water storage (Scanlon, 2005), tree ring growth (Maelstrom et al., 1997), spring green up (Park et al., 2015), spatial patterns in precipitation and growth (Wang et al., 2001, 2003), rapid canopy development and leaf area (Park et al., 2015, Filippa et al., 2018), plant stress (Fenstermaker et al., 1997) and climate - biosphere interactions at the continental scale (Zang et al 2005). NDVI can be generated from satellite data (Zang et al., 2005; Devitt et al., 2010), phenocams (Snyder et al., 2019), fixed sensors (Baghzouz et al., 2010) and portable spectral radiometers (Devitt et al., 2005). Although satellite data can be acquired over large areas, how well the values represent the dynamic change occurring at the plant level (i.e. what is the satellite capturing?), especially the ability to assess understory vegetation, spring green up and plant response to summer time soil moisture dry down requires further detailed field validation.

In Nevada, approximately 80 percent of total forestland is comprised of pinyon-juniper woodlands, the highest percentage of any state in the American southwest (Eyre, 1980). These ecosystems have declined regionally in response to severe regional drought events and wildfire (Floyd et al., 2004; Breshears et al., 2009), yet are actually expanding in much of the Great Basin, including northern Nevada (Shaw et al., 2005; Coates et al., 2017). Differences in the physiology of isohydric pinyon pines and anisohydric junipers have led to differing individual responses to variation in climate (Plaut et al., 2013; Krofcheck et al., 2015; Hudson et al., 2018), and have also been found to underlie variation in whole-ecosystem functioning across a range of environmental conditions (Krofcheck, 2014; Morillas, 2017). Indeed, whole-ecosystem functioning and responses to climate variation in pinyon-juniper woodlands are strongly shaped by the individual responses of et al., ecosystem components (tree and shrub composition, understory herbaceous vegetation, and bare soil) to seasonal variation in soil moisture (Flanagan et al., 1992; West et al., 2007; Petrie et al., 2015). It follows that the composition and physical structure of pinyon-juniper ecosystems underlie larger-scale evaluation using remote sensing indices (Krofcheck et al., 
2015), yet these relationships have not been explored for the wide diversity in composition and physical structure exhibited by pinyon-juniper woodlands in the American southwest. For this reason we propose that pinyon-juniper ecosystems offer a unique opportunity to elucidate how different components of ecological response are captured in remote sensing indices. An important aspect of understanding landscape and regional responses of semiarid ecosystems to precipitation and soil moisture variation is determining the ecosystem components that shape spatial signals obtained from satellite remote sensing. Pinyon-juniper ecosystems may be an ideal ecosystem type for doing this in Nevada because water use of these plant communities has been documented to be intricately coupled to precipitation, which at some sites has led to a zero recharge component in the water balance (Devitt et al., 2018).

We conducted a manipulative water addition experiment in a pinyon-juniper woodland in southern Nevada, USA, to better understand how the et al., sensitivity of components of the land surface comprised of tree and shrub species (Pinus monophylla, Purshia stansburiana, Juniperus osteosperma and Symphoricarpos albus), and bare soil responded to seasonal variation in soil moisture availability and sustained periods of soil moisture increase and decline, and to determine to what degree and under what conditions et al., these individual responses et al., were captured by satellite measures of NDVI . Our specific goals were to: (1) determine the response of plant and bare soil NDVI to variation in seasonal soil moisture and potential evapotranspiration; (2) determine how NDVI responses differed for plants et al., under an experimental water addition treatment that increased soil moisture; (3) compare stand-integrated and satellite measures of NDVI; and (4) determine the plant and vegetation components most strongly associated with stand-integrated and satellite NDVI variation in wet and dry periods, and during seasonal green-up and dry-down periods. We hypothesized that ecosystem components (plant species and bare soil) would have unique NDVI signatures that differed across wet and dry conditions, such that their relationship to satellite NDVI also differed during these time periods. Our study provides insight on how biotic and abiotic ecosystem components and their differing responses to seasonal water availability underlie measures usually attributed to the ecosystem as a whole.

\section{Materials and Methods}

\subsection{Site Description}

Table 1. Morphological characteristics (average $+/$ - standard deviation) of plants under control vs supplemental water treatments

\begin{tabular}{lllll}
\hline Species & Treatment & Basal Canopy Area & Height $(\mathrm{m})$ & Trunk Circumference $(\mathrm{cm})^{*}$ \\
\hline Cliffrose & Water & $4.05+/-2.01$ & $1.94+/-0.35$ & $21.83+/-4.31$ \\
Cliffrose & Control & $2.41+/-1.65$ & $1.48+/-0.76$ & $20.87+/-0.81$ \\
Pinyon Pine & Water & $4.11+/-0.68$ & $3.25+/-0.70$ & $33.35+/-1.91$ \\
Pinyon Pine & Control & $5.54+/-3.83$ & $2.88+/-0.74$ & $17.30+/-4.00$ \\
Snowberry & Water & $1.45+/-0.17$ & $0.94+/-0.28$ & $3.98+/-1.19$ \\
Snowberry & Control & $1.45+/-0.17$ & $0.77+/-0.09$ & $4.19+/-0.19$ \\
Utah Juniper & Water & $3.81+/-2.73$ & $2.34+/-0.35$ & $21.47+/-4.17$ \\
Utah Juniper & Control & $3.04+/-0.87$ & $2.32+/-0.36$ & $18.93+/-9.62$ \\
\hline
\end{tabular}

Breast height, except snowberry where trunk circumference was measured at the midpoint between the soil surface and the first branch

The experiment was designed to compare and contrast sensitivity in the in situ spectral response of the individual components of a pinyon-juniper woodland composed of 3 tree species, 1 shrub species, and bare soil to supplemental water vs. control conditions receiving only ambient precipitation. In addition, we wanted to determine how the stand scale spectral response from satellite imagery was influenced by these different ecosystem components during seasonal periods of soil moisture availability and deficit and the transitional periods between them. Plant species selected included pinyon pine (Pinus monophylla), Utah juniper (Juniperus osteosperma), cliffrose (Purshia stansburiana) and snowberry (Symphoricarpos albus; Table 1). All study plants were at least $8 \mathrm{~m}$ from other test plants. The percent cover (canopy cover of the ground) of each species in the study area was quantified as $16.5 \%$ pinyon pine, $12.0 \%$ Utah juniper, $10.9 \%$ cliffrose, $4.6 \%$ snowberry, with an additional $9.0 \%$ of the area comprised of sagebrush, ephedra, yucca and opuntia species. The total plant cover was 
estimated at 53\% leaving the remaining as open bare soil. Pinyon pine had the largest basal canopy areas $(5.54+/-$ $3.83 \mathrm{~m}^{2}$, control), tree heights $(3.25+/-0.70 \mathrm{~m}$, irrigated) and largest trunk circumferences $(33.35+/-1.91 \mathrm{~cm}$, irrigated) of all species (Table 1).Our study was conducted from 2012-2013 in a mature, south facing pinyon-juniper plant community within the Sheep Mountain Range of southern Nevada at an elevation of $2065 \mathrm{~m}$ $(36.572808 \mathrm{~N},-115.204060 \mathrm{~W})$. The soil was classified as a loamy skeletal mixed superactive mesic calcic agriustoll, providing good drainage but limiting most root development to the upper $75 \mathrm{~cm}$.

\subsection{Experimental Design and Implementation}

Our experiment focused on the spectral response of plant species and bare soil located within one Landsat pixel $\left(30 \mathrm{~m}^{2}\right)$ centered on the meteorological tower (control), and therefore was not plot-based. Near the meteorological tower, plants and bare soil were designated as controls and only received ambient precipitation, whereas plants receiving supplemental water were located approximately $50 \mathrm{~m}$ to the west of the tower (although we processed the NDVI values for this area we chose not to report these because most of the plants in the pixel would not have received supplemental water).

Six plants of each species were selected for the study (three receiving supplemental water and three as controls). Plants selected for supplemental water had $15 \mathrm{~cm}$ soil berms constructed to capture the basal canopy edge of each plant. In all cases the area within the berms was relatively level and did not require surface adjustments to enhance a more even spread of the water (Table 2). Experimental plants received an additional 50\% of total ambient rainfall delivered during six periods, adjusted for plant basal area (Table 2). Each plant received the equivalent of $10.85 \mathrm{~cm}$ of supplemental water during the NDVI monitoring period.

Table 2. Water additions in $\mathrm{cm}$ based on the basal canopy area of each tree or shrub. Supplemental water was applied based on $50 \%$ of the previous measurement period. No supplemental water was applied during the winter period of $2012-2013$

\begin{tabular}{lll}
\hline Date & Precipitation $(\mathrm{cm})$ & Water Applied* $(\mathrm{cm})$ \\
\hline $5 / 08 / 2012$ & 2.31 & 1.16 \\
$7 / 30 / 2012$ & 2.24 & 1.12 \\
$8 / 30 / 2012$ & 9.37 & 4.69 \\
$10 / 02 / 2012$ & 2.18 & 1.09 \\
$11 / 14 / 2012$ & 3.78 & 1.89 \\
$4 / 02 / 2013$ & 1.80 & 0.90 \\
\hline
\end{tabular}

*Soil berms were built at the canopy edge of each irrigated plant. Although the irrigated plants received the same depth of water, the amount in liters varied based on the basal canopy area.

\subsection{Meteorological and Soil Moisture Data}

A 10 m meteorological tower which is part of the NevCAN climate change monitoring network (Mensing et al., 2013) provided precipitation measurements (tipping bucket, Campbell Scientific, Logan UT), reference evapotranspiration estimates (ET ref, Penman), and volumetric soil moisture (VWC: $\mathrm{m}^{3} \mathrm{~m}^{-3}$ ) measurements at the 10 and $20 \mathrm{~cm}$ depth (Acclima TDT, Meridian ID) during the experiment . The soil moisture sensors were located adjacent to the tower which contained all four species with plants separated by less than $2.5 \mathrm{~m}$ (located in the interspace area, roots observed when inserting the sensors). We calculated daily totals for precipitation and $\mathrm{ET}_{\text {ref, }}$ and daily mean values of soil moisture.

\subsection{Ground and Satellite-Based NDVI Measurements}

Each plant (both control and experimental) had an NDVI sensor (Normalized Difference Vegetation Index) mounted approximately $30 \mathrm{~cm}$ above the canopy to assess NDVI over the two year period (plus a bare soil control site). Skye 2-channel NDVI sensors (Skye Instruments Llandrindod Wells, Powys UK) were installed to measure incoming and outgoing red and near infrared wavelengths. The sensor channels were calibrated to Landsat Thematic Mapper red and near infrared bands, i.e., 630 - 690 and $760-900 \mathrm{~nm}$, respectively, to allow for comparison with satellite data. The maximum wavelength tolerance of these sensors is $+/-3 \mathrm{~nm}$, but typically the sensors have a much finer tolerance. All trees selected for the study were less than $4 \mathrm{~m}$ in height, allowing for placement of the sensors. NDVI sensors were mounted on a horizontal rod that included a leveling bubble to 
indicate proper horizontal positon, and were adjusted as needed. All sensors were wired to a data logger (Campbell Scientific, Logan UT). NDVI values were generated on an hourly basis. We chose to average values between 1200 and 1400 hours for statistical analysis. NDVI values acquired from all sensors were assessed for outliers that were typically associated with the fall winter months when the angle of the sun was lower. During spring and summer, approximately $7 \%$ of the NDVI values did not conform to the previous 5 day moving trend and were removed; whereas during fall and winter approximately $32 \%$ of NDVI values were removed (no attempt was made to gap fill the data). Snowberry during the early fall to winter period (2012) had two 15 day periods when little data was acceptable (not conforming with the previous 5 day moving trend, totaling $8.8 \%$ of the 2012 data set).

Landsat NDVI data were acquired for the tower area (control plants) using coordinates acquired with a GPS. Although other vegetation indices (such as the soil adjusted vegetation index - SAVI (Huete, 1988) and modified SAVI - MSAVI (Qi, 1994) might be more applicable for an area with a high percentage of bare soil, the NDVI was acquired to provide a direct comparison with the ground-based NDVI measurements. The NDVI data were extracted from the Climate Engine website (climateengine.org; Huntington et al., 2017) developed by faculty from the Desert Research Institute and University of Idaho using Google Earth Engine. This website enables the user to extract time series Landsat NDVI data for specific locations and ensures that all data (regardless of year and Landsat satellite) are processed in a uniform manner, which allows reliable comparison of NDVI values over time. Because the only Landsat data available during 2012 was from Landsat 7, for which the scan-line corrector failed in 2003 , there was limited data coverage for the study site pixel locations. Therefore, 2012 was excluded from the data analysis.

\subsection{Plant Physiology and Growth}

Plant physiological responses were assessed (six times during the experimental period) by measuring mid-day leaf xylem water potential (Scholander pressure bomb, PMS, Albany OR), chlorophyll index (Field Scout CM1000, Spectrum Technologies, Aurora IL) and tissue moisture content (fresh weight (g) minus dry weight (g))/ fresh weight $(\mathrm{g})$ ). Only leaves/needles from the outer canopy exposed to direct sunlight were selected for measurement. In the case of tissue moisture content, leaves/needles were harvested and placed in bags that were sealed and transported to the lab in coolers with ice. Tissue was weighed upon return to the lab (same day) and then the tissue was oven dried at $70^{\circ} \mathrm{C}$ for 48 hours.

After completion of the experiment in 2013, all tree species were cored at chest height. In the case of snowberry which is a small deciduous shrub, main trunk cuttings were taken to provide cross sectional views of the growth rings. All cores and cuttings were transported to the lab where they were dried before mounting and sanding. The cores and cuttings were viewed under a microscope and ring widths were measured for the most recent nine year period. The last two year period reflecting the influence of the supplemental water was compared to the previous seven year period in which no supplemental water was applied, generating a water/non water growth ring width ratio.

\subsection{Data Analysis}

The data were analyzed using SigmaStat and graphs were generated using SigmaPlot (San Jose CA). Descriptive statistics, linear regression analysis and analysis of variance were used to analyze the data (Soil moisture vs. ET ref minus precipitation curves, NDVI response curves, NDVI vs. plant physiological measurements and growth ring width ratios). Interpretation of data was based on achieving statistical significance at the $\mathrm{p} \leq 0.05$ level.

\section{Results}

\subsection{Environmental Conditions}

NDVI Sensor and plant physiological measurements were taken over a two-year period in 2012-2013, during

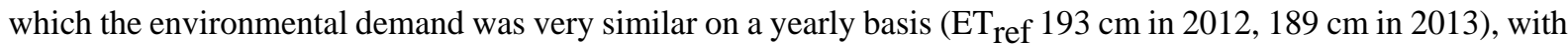
highest monthly et al., $\mathrm{ET}_{\text {ref }}$ in June $(29.0 \mathrm{~cm}$ in $2012,28.8 \mathrm{~cm}$ in 2013). Total annual rainfall was also similar in both years (35.3 cm in 2012, $34.1 \mathrm{~cm}$ in 2013), with 55\% of this total occurring in July and August of 2012 and 53\% in 2013. No rainfall occurred in June of either 2012 or 2013, and in 2012 no rainfall occurred in May. et al., Volumetric water content (VWC) at $10 \mathrm{~cm}$ depth responded to rainfall events and subsequent water loss to

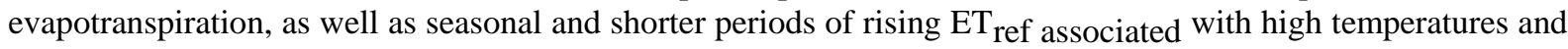
low precipitation (Figure 1A). However at the $20 \mathrm{~cm}$ depth a dampening effect on VWC was observed with little variation in $2012(0.142+/-.006, \mathrm{CV} 0.04)$. VWC at the $20 \mathrm{~cm}$ depth did show a rise during the first three months of 2013 associated with the highest VWC at the $10 \mathrm{~cm}$ depth. The coefficient of variation was highest at the $10 \mathrm{~cm}$ depth in 2013 at 0.28 compared to 0.12 at the $20 \mathrm{~cm}$ depth. Seasonal dry down events occurred in spring-summer of each year. In $2012 \mathrm{VWC}$ declined over a 79 day period (April 15-July 3) from 0.285 to $0.097\left(\mathrm{~cm}^{3}\right.$ of water per 
$\mathrm{cm}^{3}$ ), and in 2013 VWC declined from 0.264 to 0.101 over a 114 day period (March 11 - July 3 ). These dry down

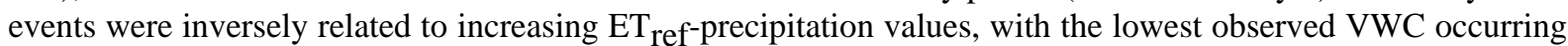

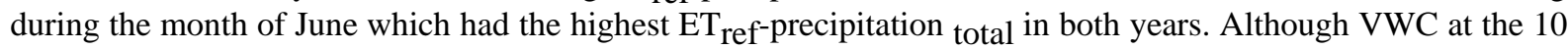
$\mathrm{cm}$ depth was very similar at the end of these two dry down events, the 2012 dry down occurred more rapidly, indicated by a steeper slope (-0.0024 in 2012, -0.0014 in 2013).

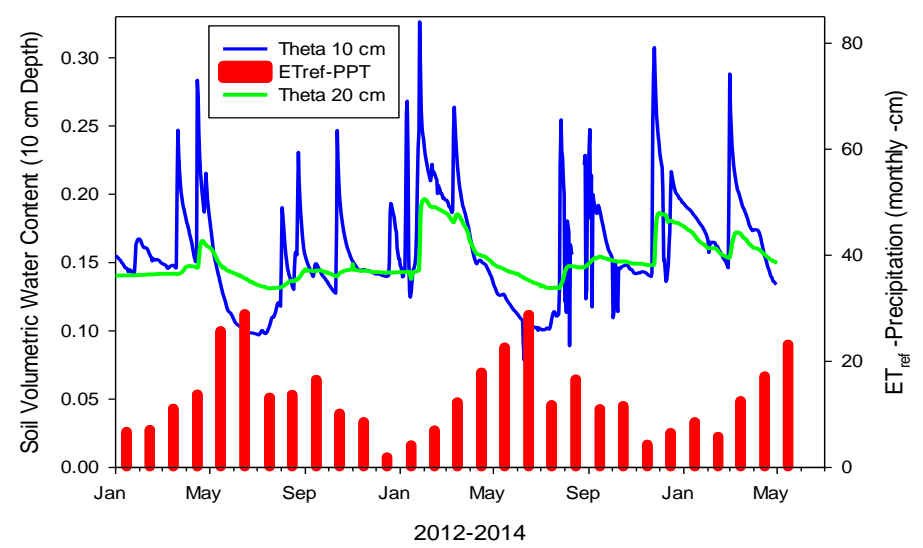

Figure 1. Soil volumetric water content a the 10 and $20 \mathrm{~cm}$ depths, along with monthly totals of $\mathrm{ET}_{\text {ref- }}$ precipitation in $\mathrm{cm}$

\subsection{Soil NDVI}

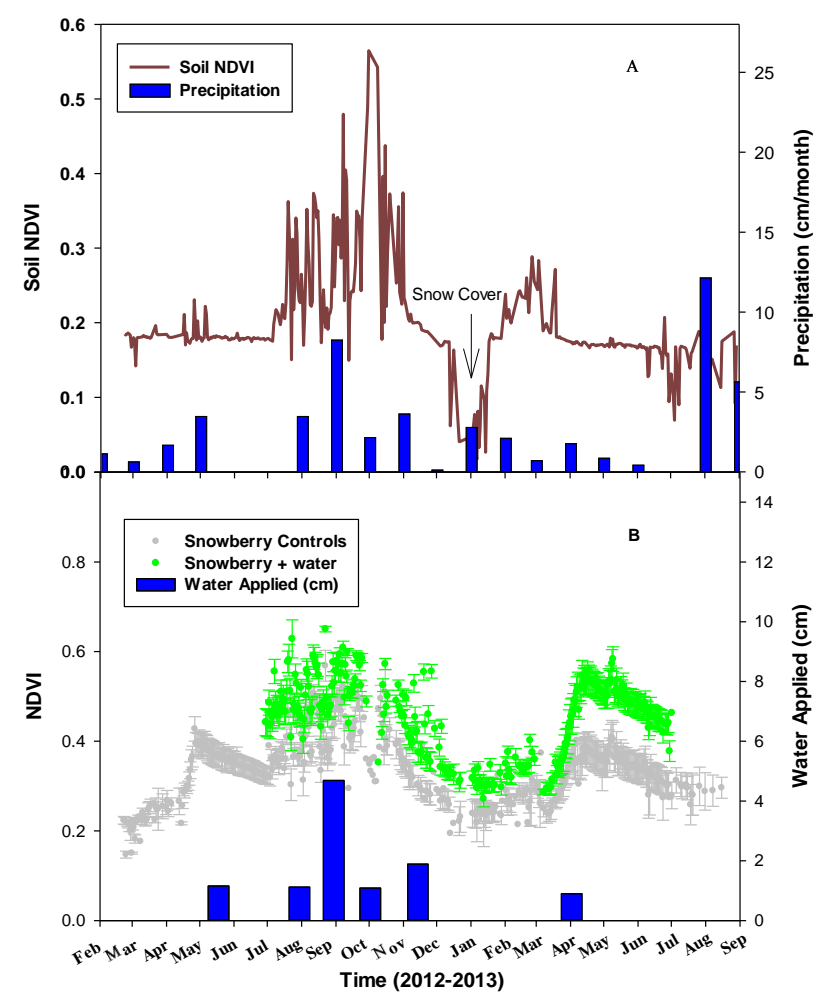

Figure 2. Bare soil NDVI over time along with monthly precipitation totals in $\mathrm{cm}$ (Graph A). Canopy level NDVI values for snowberry (Graph B) over time for both control plants and those receiving supplemental water on six separate dates during the experimental period

Soil NDVI was more variable during months with relatively high P and VWC, especially in 2012 compared to 2013 (Figure 2A). During these wet periods soil NDVI increased to $>0.50$. The months of October and November of 2012 were especially problematic with $52 \%$ of the soil NDVI values rejected following data removal protocol, due to unknown reasons However, during the spring-summer dry down periods (Feb-June), soil NDVI was 
relatively stable with NDVI values averaging $0.18+/-0.01$ in 2012 and $0.17+/-0.01$ in 2013 . We found that the temporal soil NDVI response was not predictable based on $\mathrm{P}$ or $\mathrm{ET}_{\text {ref }}$ when analyzing the full data set $(\mathrm{p}>0.05)$, or during a seasonal wet period from July 2012 -February 2013 (p>0.05). However, when the dry down period of 2013 (March-June) was assessed separately, soil NDVI declined linearly from approximately 0.19 to 0.16 as VWC at the $10 \mathrm{~cm}$ depth declined from 0.27 to $0.09\left(\mathrm{R}^{2}=0.31, \mathrm{p}<0.001\right)$. Based on a coefficient of variation of 0.34 for the soil NDVI data set, we estimated the number of data points required to get within $10 \%$ of the true mean at the 0.05 level of significance to be 444, whereas the soil NDVI data set contained 391 data points. This suggests that a larger temporal NDVI data set would be needed to capture the full range of NDVI values during our 2012-2013 experimental period.

\subsection{Canopy NDVI}

All three tree species revealed non-significant differences in et al., canopy NDVI et al., between the control and water addition treatments (NS, p>0.05 Figures 3A,B and C), with the highest NDVI values occurring during et al., July-October 2012 ( pinyon pine $0.70+/-0.07$ control vs. $0.75+/-0.05$ water, Utah juniper $0.77+/-0.04$ control vs. $0.81+/-0.04$ water, cliffrose $0.57+/-0.08$ control vs. $0.59+/-0.06$ water). In contrast, snowberry NDVI was statistically higher in the water addition treatment $(\mathrm{p}<0.05)$ during 4 periods: June-November 2012, December-February2012-2013, March-April 2013 and May-June 2013 (Figure 2B). Canopy NDVI values for the

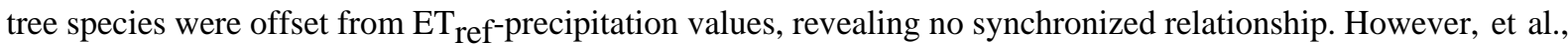
snowberry NDVI in the water addition treatment tracked the general $\mathrm{ET}_{\text {ref-precipitation curve but was reduced }}$

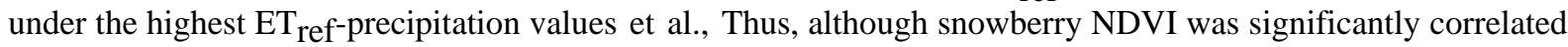
to ETref-precipitation $(\mathrm{p}=0.008)$ it accounted for only a moderate amount of variation in the NDVI values $\left(\mathrm{R}^{2}=0.34\right)$.

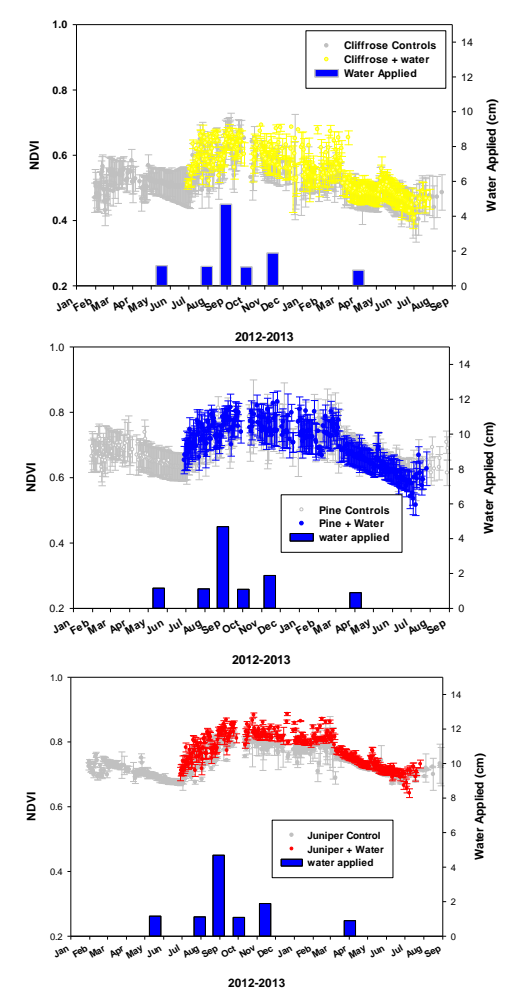

Figure 3. Canopy level NDVI values for cliffrose (Upper Graph), Pinyon pine (Middle Graph) and Utah juniper (Lower Graph) over time along with the six supplemental water applications during the experimental period 


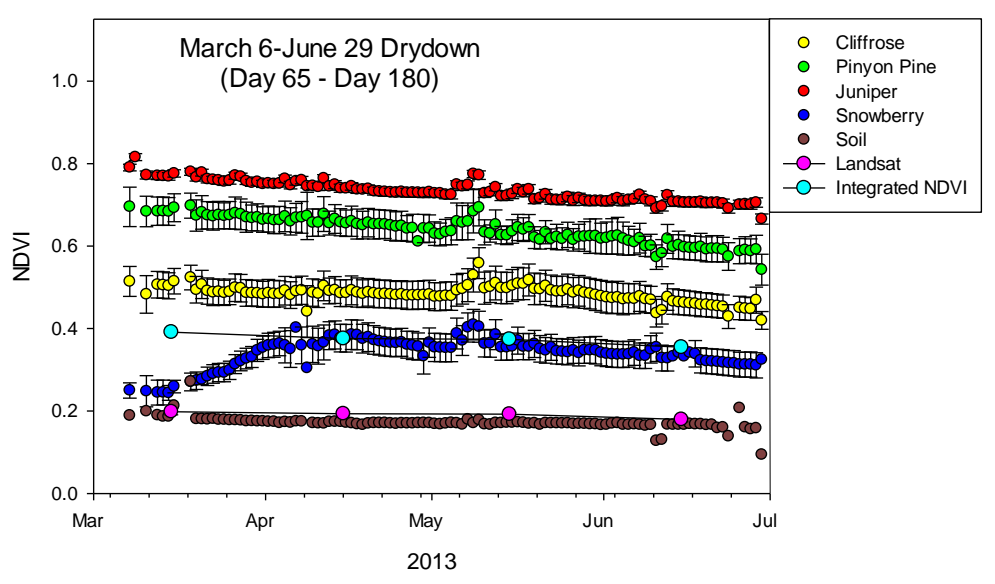

Figure 4. Canopy level NDVI values for all three tree species and one shrub species during the spring early summer dry down period of the second year. In addition, bare soil NSDVI, Landsat and integrated NDVI values are also shown

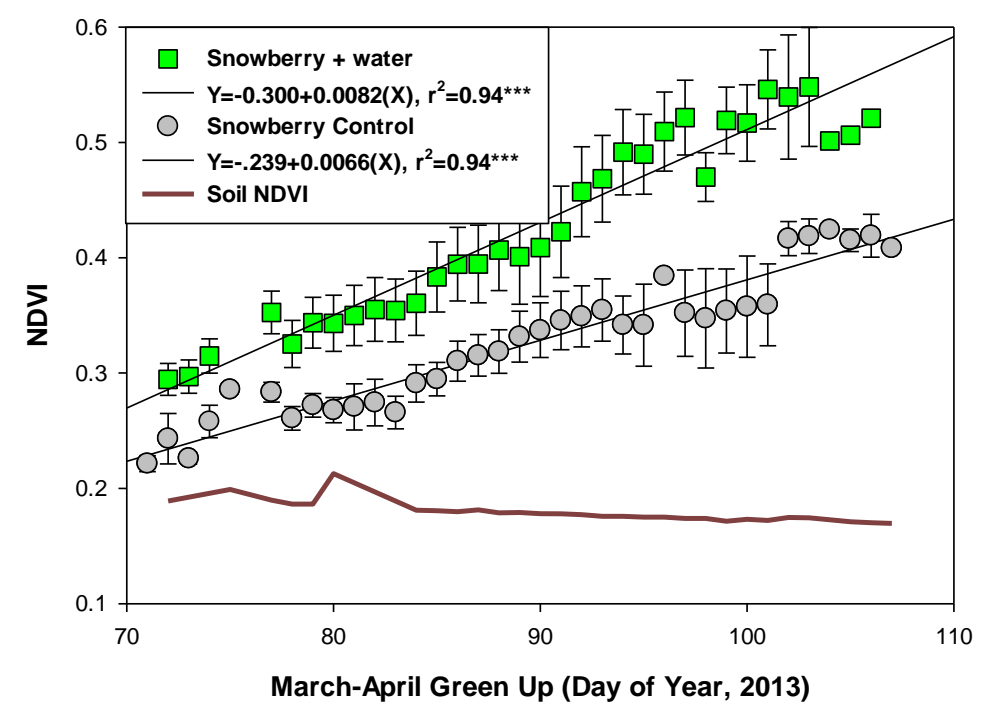

Figure 5. Canopy level NDVI values of snowberry receiving supplemental water contrasted with control plants during the spring green up period of the second year of the study. In addition, bare soil NDVI values area also reported over this 40 day period

Canopy NDVI for both control and supplemental water treatments) revealed differences between species ( $\mathrm{p}<0.001)$, especially during the spring dry down period of March-June, with snowberry breaking dormancy during mid-March (Figure 4, control only shown). NDVI values were correlated with soil VWC (10 cm depth) during this dry down period, with the exception of cliffrose (pinyon pine, Utah juniper and snowberry $\mathrm{R}^{2}=$ 0.62-0.72, $\mathrm{p}<0.001)$. Because we only had soil water content sensors in the control area near the meteorological tower, we recognize that the correlations may have been different if we had paired data with each tree. However, the data would suggest that only subtle changes in canopy NDVI occurred over a soil water content decline from approximately 0.25 to 0.10 at the $10 \mathrm{~cm}$ depth. No plants revealed an immediate NDVI response to rainfall events or supplemental water additions (day of or next day), However all trees in 2012 did reveal a significant shift in NDVI following the transition from May and June which received no precipitation to July which received $11.2 \mathrm{~cm}$. Although June of 2013 also received no precipitation and July of 2013 was the wettest July $(12.17 \mathrm{~cm})$ over the 2012-2020 period (NevCAN), no NDVI shift was observed. et al., NDVI values shifted higher in a linear fashion over time during the July wet-up period. Cliffrose NDVI (+water $\mathrm{R}^{2}=0.29, \mathrm{p}<0.001$ and control trees, $\mathrm{R}^{2} 0.42$, $\mathrm{p}<0.001$ ), Pinyon pine NDVI (+water $\mathrm{R}^{2}=0.30, \mathrm{p}<0.001$ and control trees, $\mathrm{R}^{2}=0.17, \mathrm{p}=0.013$ ) and Utah juniper NDVI (+water $\mathrm{R}^{2}=0.37, \mathrm{p}<0.001$ and control trees $\mathrm{R}^{2}=0.26, \mathrm{p}=0.001$ ) were all found to be correlated on a temporal basis. Although snowberry, also showed no immediate NDVI response to rainfall or supplemental water (day of or 
next day), nor to the July wet up (recognizing that measurements on the irrigated plants did not occur until July in 2012), snowberry did reveal a statistically significant offset $(p<0.05)$ from the control plants over the entire experimental period (Figure 2B). et al., Snowberry was unique in its NDVI response during the spring green up period of 2013 (Figure 5). NDVI values began to increase in early March, with both control and water treatment plants revealing a highly linear shift over the next 40 days. No NDVI offset was observed with plants breaking dormancy earlier associated with supplemental water. There was however a clear separation $(\mathrm{p}<0.001)$ between the two NDVI green up curves with those plants receiving supplemental water having a higher more positive slope (0.008) than observed with the control plants $(0.005)$.

\subsection{Plant Physiological Response}
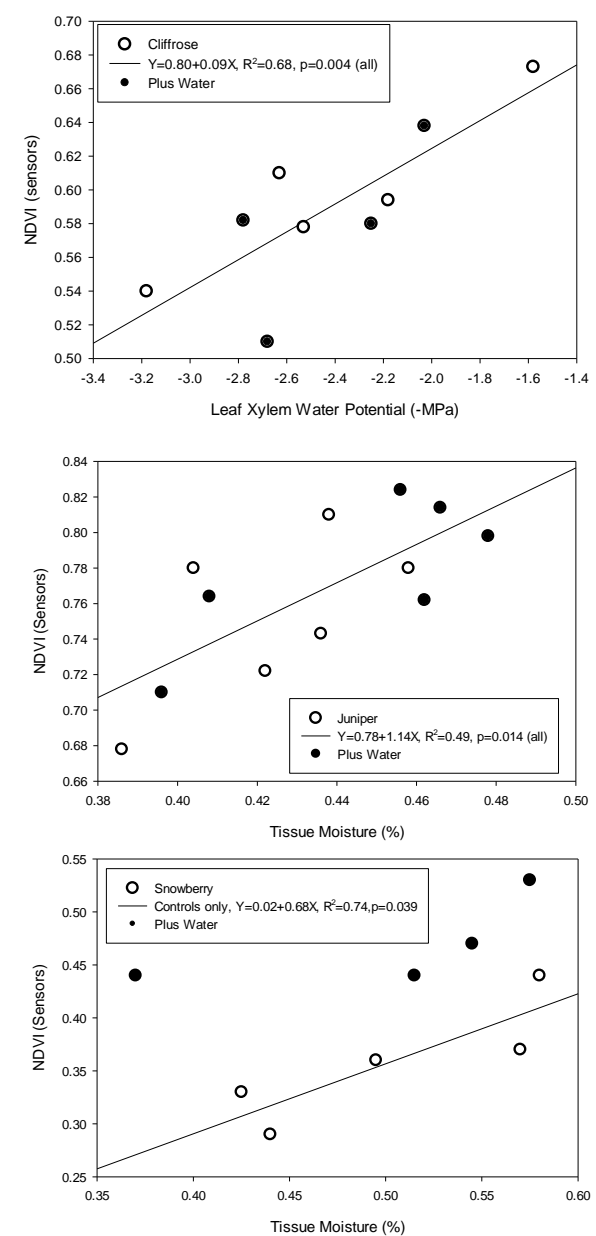

Figure 6. Canopy level NDVI values for cliffrose as a function of leaf xylem water potential (Upper Graph). Canopy level NDVI values for Utah juniper as a function of tissue moisture content (middle graph) and canopy level NDVI for snowberry as a function of tissue moisture content (Lower Graph)

Species-level NDVI was cross correlated with leaf xylem water potential, tissue moisture content and chlorophyll index values, However no significant correlations were observed with pinyon pine. We found a significant correlation between cliffrose NDVI and leaf xylem water potential (Figure $6, \mathrm{R}^{2}=0.68, \mathrm{p}=0.004$ ), with NDVI values declining from 0.67 to 0.51 , with a decline in leaf xylem water potential of-1.6 MPa. Juniper NDVI increased as tissue moisture content increased from 0.385 to 0.480 (Figure 6, no other correlations existed with Utah juniper). For snowberry, NDVI of control plants were positively correlated with increasing tissue moisture content $\left(\mathrm{R}^{2}=0.74, \mathrm{p}=0.039, \mathrm{n}=5\right)$. All of the NDVI values of snowberry plants receiving supplemental water had higher values than predicted based on the control response, suggesting that additional water may have had a greater impact on canopy density, leaf morphology and photosynthesis than simply on elevating tissue moisture content.

The relationship between chlorophyll index and NDVI sensor values separated based on species $(\mathrm{p}<0.05)$. However, only cliffrose and snowberry revealed significant correlations between these two parameters $\left(R^{2}=0.49\right.$, 
$\mathrm{p}<0.01$ and $\mathrm{R}^{2}=0.63, \mathrm{p}<0.01$ respectively). However, when values from all four species were used to generate a response curve, a highly significant correlation existed (Figure 7. $R^{2}=0.86, p<0.001$ ). The chlorophyll index values were generated from red and near infrared reflectance, so the correlation with the NDVI sensor values was expected, providing another check on the sensors. The response curve was curvi-linear; suggesting that canopy NDVI was approaching saturation at around $\sim 0.80$, associated with chlorophyll index values of $\sim 290$.
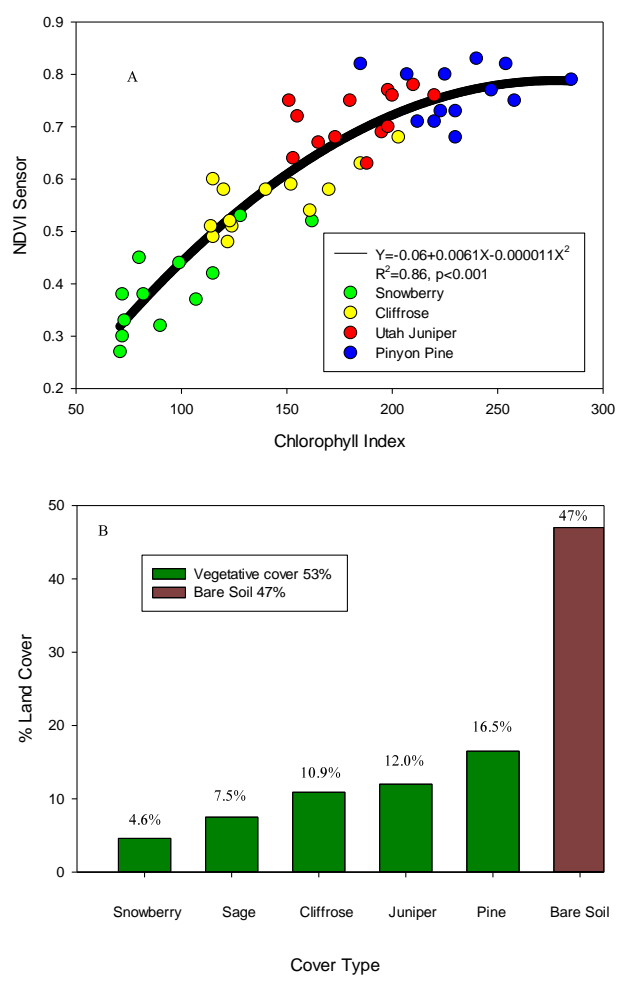

Figure 7. Canopy level NDVI values for all three tree species and one shrub species as a function of the chlorophyll index (Graph A). \% land cover of the major plant species in the test area along with an estimate of the bare soil cover (Graph B)

We assessed if supplemental water led to any differences in growth by measuring annual growth ring widths (Table 3). Both pinyon pine and cliffrose revealed significantly higher growth ring width ratios $(\mathrm{p}<0.05)$ for those trees receiving supplemental water. Utah juniper had higher average ratios for the supplemental water treatment than the control treatment but significant variation in the data led to non-significant differences. In the case of snowberry the average values were extremely similar (+water $1.00+/-0.05$ vs. control $1.13+/-0.08$ ) and not statistically different.

Table 3. Ratio of the average ring growth width for the period of 2012-2013 divided by the average ring growth width for the seven-year period prior to the experiment. Values are based on three replicates for each species in the control and irrigation treatments. $p$ values are based on a t test contrasting the ratio from control plants vs the ratio from plants receiving supplemental water

\begin{tabular}{llll}
\hline & Control & Irrigation & $\mathrm{p}$ Value \\
\hline Cliffrose & $0.96+/-0.08$ & $1.35+/-0.08$ & 0.030 \\
Pinyon Pine & $0.72+/-0.35$ & $1.38+/-0.06$ & 0.047 \\
Snowberry & $1.13 \_-0.08$ & $1.00+/-0.05$ & 0.200 \\
Utah Juniper & $1.63+/-0.79$ & $2.39+/-0.59$ & 0.200 \\
\hline
\end{tabular}




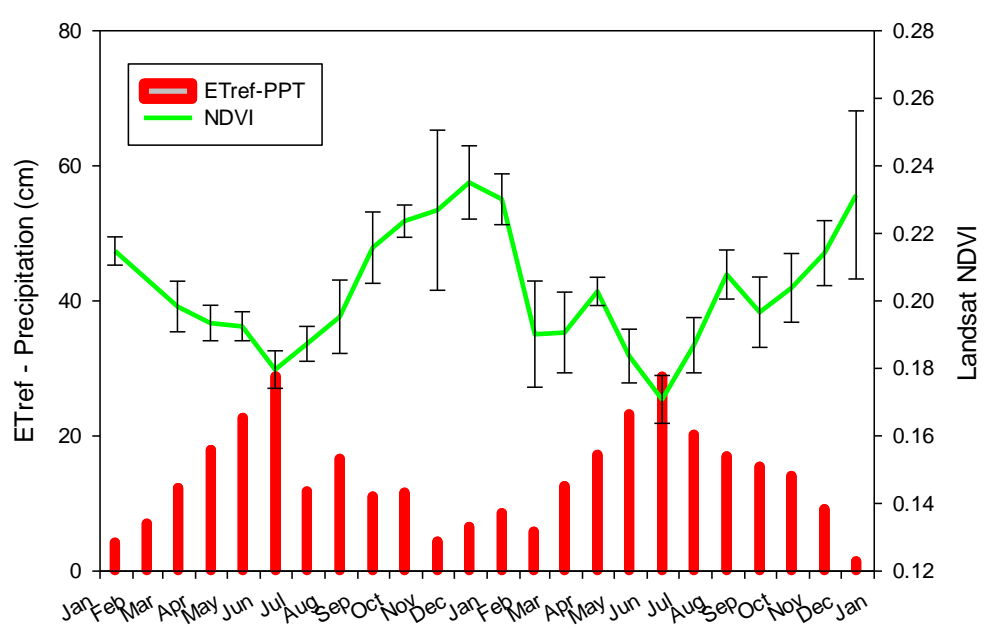

$2013-2014$

Figure 8. Landsat NDVI values as a function of the monthly totals of $\mathrm{ET}_{\text {ref-precipitation }(\mathrm{cm})}$

Landsat NDVI values (control area) revealed an inverse sinusoidal relationship with $\mathrm{ET}_{\text {ref-precipitation }}\left(\mathrm{R}^{2}=0.59\right.$;

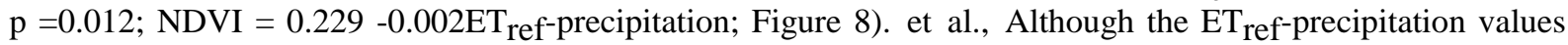
varied over a wide range $(2 \mathrm{~cm}$ to $\sim 30 \mathrm{~cm})$, NDVI was less variable $(0.17$ to 0.23$)$. Plant NDVI was statistically different from the Landsat NDVI (juniper $0.74+/-0.04$, pine $0.63+/-0.05$, cliffrose $0.53+/-0.02$, snowberry 0.30 $+/-0.05, \mathrm{p}<0.001)$, with no significant difference $(\mathrm{p}>0.05)$ between the bare soil NDVI and the Landsat NDVI. Average monthly Landsat NDVI in 2013 was $0.19+/-0.01$, while bare soil NDVI was $0.17+/-0.01$.

Proportionally-weighted monthly ground NDVI (i.e. integrated NDVI) for each species and bare soil (control area) were statistically higher $(0.37+/-0.03, \mathrm{p}<0.001)$ than monthly Landsat NDVI $(0.19+/-0.01)$. et al., For the individual plant and soil components of integrated NDVI, only Utah juniper $\left(\mathrm{R}^{2}=0.84, \mathrm{p}=0.003\right)$ and pinyon pine $\left(\mathrm{R}^{2}=0.77\right.$. $\left.\mathrm{p}=0.01\right)$ NDVI were correlated to Landsat NDVI. Multiple regression analysis revealed that $95 \%$ of the variation in Landsat NDVI (2013) could be accounted for based on bare soil NDVI values and pinyon pine NDVI values (Landsat NDVI $=0.0765-0.157$ (soil NDVI) +.231 (Pine NDVI), $\mathrm{R}^{2}=0.95, \mathrm{p}<0.001$ ). Pine was the only species accepted into the regression, not having the highest NDVI values (Utah juniper) but representing the species with the largest \% cover $(16.5 \%)$. Note also the negative coefficient for the bare soil, representing an offset adjustment for the correlation.

\section{Discussion}

Forest canopies are dynamic living surfaces. Spectral reflectance of such surfaces have been shown to detect the ebb and flow of plant available water and associated vegetation responses, reflecting an ecological response to environmental variation (Pettorelli et al., 2005; Devitt et al., 2018) In addition, spectral reflectance can detect spring green up and leaf development and senescence associated with deciduous species (Kaye \& Wagner, 2014; Park et al., 2015; Xu et al., 2019). Climate change has the potential to significantly alter these oscillations occurring at the plant and stand level, especially in the American southwest where growth and productivity of plants is strongly coupled to water availability (Bunting et al., 2017). In our study we were able to detect both short term (one month) and seasonal variation in NDVI of plant canopies that differed based on species, with individual Utah juniper trees having the highest canopy NDVI values and snowberry shrubs the lowest canopy NDVI values.

Supplemental water did not lead to higher NDVI values for the three tree species. In contrast, NDVI was statistically higher in the deciduous shrub receiving supplemental water compared to the control treatment. et al., Although none of the tree or shrub species exhibited an NDVI response to the supplemental water applications or precipitation on the order of 24 hours following these events, all of the tree species did reveal a rise in NDVI values in 2012 during the month of July which received precipitation following a two month period with no precipitation. Noting that 2012 was listed as a moderate La Nina year (NOAA, 2021). Such a response was not observed in 2013 which had only the month of June without precipitation. Others have reported sharp increases in NDVI following major precipitation events after a drought period (Wang et al., 2003). While still others have reported a lag time NDVI response to precipitation in the range of days (Wang, 2003; Baghzouz et al., 2010) but also months (Bunting et al., 2017) which complicates interpretation of real time values. 
We were able to gain insight into the water status of a pinyon juniper woodland by tracking soil moisture, $\mathrm{ET}_{\text {ref }}$ and precipitation. Soil moisture responded to well defined dry down periods in both years of our study, which occurred at $10 \mathrm{~cm}$ depth but did not occur at $20 \mathrm{~cm}$. et al., We recognize that the buffered NDVI response in the trees in our study could be related to the fact that forest trees are typically deep rooted compared to shrubs. Soil moisture levels during the experimental period of our study may not have reached a limiting status especially at the deeper depths (not assessed), as others have noted that NDVI only decreased when soil moisture became limiting (Price et al., 1993) while others have reported only a slow rise in NDVI values with increased precipitation (Nicholson \& Farrar, 1994). Bunting et al. (2017) noted in shrubland and woodland communities that a possible explanation for a lack in spectral reflectance response may be because of adequate water availability. All three of the tree species in our study are known to retain their needles and/or leaves for multiple years; nine years for pinyon pine (USDA, 2020), five years for Utah juniper (Peek et al., 2006) and two years for cliffrose (USU Tree Browser, 2020) which could further complicate interpretation of any real time NDVI response in trees. Such differences in age of needles in coniferous species has been shown to cause spatial variation in needle spectra which also varies seasonally, this combined with different spectral properties of bark make the interpretation of et al., spectral data more challenging (Rautiainen et al., 2018).

It has long been proposed that evergreen species (because they have long lived needles or leaves) would show a physiological response to increased resources whereas deciduous species with leaves that drop on an annual basis would respond to increased resources morphologically (Grime \& Campbell, 1991). In our study the three evergreen tree species revealed an NDVI canopy response to increased precipitation in July of 2012 but not a statistically significant response to supplemental water over the experimental period. Although NDVI was found to be correlated with leaf xylem water potential (cliffrose) and tissue moisture content (Utah juniper) the data did not separate based on treatment. Only ring growth width revealed a clear response to supplemental water (increase in pinyon pine and cliffrose). Whereas snowberry the deciduous shrub revealed an NDVI canopy response over the entire growing period (statistically different from the control) but especially during spring green up, suggesting a possible response in canopy density (morphological response). This was especially clear in the second year when we were able to capture a very distinct green up period associated with a carry-over effect from the first year of the study accentuated by the final supplemental water application occurring during the second year green up period. These greater slopes for the shrubs that were provided supplemental water suggested a more rapid canopy development (Park et al., 2015). Xu (2019) reported that increased precipitation occurring during the spring period regulated the sensitivity of the spring green up to warming spring temperatures. Others have noted a similar carry over effect from the previous year (Sala et al., 2012). This carry over effect often impacts the spring green up response, which is attributed to the accumulation and storage of non-structural carbohydrates which are mobilized to support new growth (Kozlowski, 1991; Chapin, 1990; Landhauser, 2012). Bunting et al. (2017) reported results that supported the hypothesis that production is amplified in a drying legacy because of previous wet year carry over effects.

NDVI at the individual plant canopy level revealed statistically significant differences between the four species and bare soil. Although the individual plant canopy NDVI values were statistically different from Landsat NDVI, bare soil NDVI was not. Such differences between plant canopy and forest canopy NDVI values was expected based on differences in canopy architectures, shadow effects, viewing angles, leaf angles and stand density (Hernandez-Clemente et al., 2011). NDVI Landsat values revealed a narrow range but still correlated with

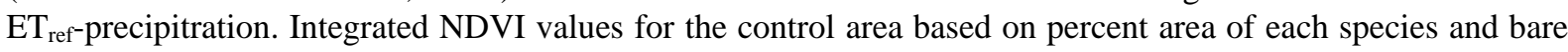
soil weighted with the NDVI sensor values were approximately two times larger than the Landsat values, indicating that the contribution from the higher NDVI canopy sensor values to the Landsat values were being significantly impacted by the bare soil values.

We suggest that future studies may be able to gain greater perspective on ecosystem responses by using additional soil and vegetation indices assessed with insitu sensors to help extract greater information from Landsat data. Bunting et al. (2017) suggested that if the response of pinyon and juniper could be isolated, the response to climate would be more reflective of juniper. Our results indicate that the spectral response (NDVI) of Pinyon and juniper (the two species with the largest $\%$ ground cover at our site) were uniquely different with statistically higher NDVI values for juniper but both were highly correlated with Landsat NDVI values $\left(2013, R^{2}>0.75, p<0.001\right)$. Our findings support the conclusions by Snyder (2019) that the NDVI interspace (bare soil) of a pinyon juniper woodland would dominate the shape of the Landsat curve. More importantly we could account for $95 \%$ of the variation in Landsat NDVI (2013) values if we considered Pinyon pine and bare soil NDVI values, with bare soil possessing a negative coefficient which adjusted the higher pine NDVI values back into alignment with Landsat 
values. Such a response linking insitu sensor data with Landsat data demonstrated the value of ground sensors to help bridge the gap between what can be inferred at the forest canopy level and what is occurring at the plant level.

Forests are dynamic ecosystems that will be significantly impacted by climate warming and altered precipitation regimes, and thus they have an uncertain future. Pinyon juniper woodlands in particular represent a significant percentage of forest land in the American southwest. Because of the size of these woodlands, remote sensing will be relied upon heavily for monitoring the health and productivity of these trees and forests, especially how they respond to changes in climate. Extracting as much information from the satellite data will be critical in understanding the early signs of stress. Insitu sensors should play a critical role in helping to extract this information, providing greater biological significance to the data by linking changes in soil moisture to changes in canopy level processes as influenced by changes in climate. More long term sites are needed representing a wider range in bare soil cover where both precipitation and soil moisture (with depth) are monitored in association with individual trees (spectral reflectance, paired data) and larger forest sites to help minimize uncertainty in the satellite data, as different species will respond differently to fluctuations in climate based on soil moisture availability. These finer scales of spectral reflectance should enable scientists to better forecast the future of ecological systems to a warming climate.

\section{Acknowledgements}

The information reported in this manuscript is based upon work supported by the US National Science Foundation under grants EPS-0814372 and EPS-0919123. et al., The authors also wish to recognize the able assistance in the field by Mr. Fred Landau and Ms. Lena Wright.

\section{Conflict of interests}

The authors declare that there is no conflict of interests regarding the publication of this paper.

\section{References}

Allred, B. W., Bestelmeyer, B. T., Boyd, C. S., Brown, C., Davies, K. W., Ellsworth, L. M., Erickson, T. A., Fuhlendorf, S. D., Griffiths, T. V., Jansen, V., Jones, M. O., Karl, J., Maestas, J. D., Maynard, J. J., McCord, S. E., Naugle, D. E., Starns, H. D., Twidwell, D., \& Uden, D. R. (2020). Improving Landsat predictions of rangeland fractional cover with multitask learning and uncertainty Forest Ecology and Management. https://doi.org/10.1101/2020.06.10.142489

Baghzouz, M., Devitt, D. A., Fenstermaker, L. K., \& Young, M. H. (2010). Monitoring vegetation phenological cycles in two different semi-arid environmental settings using a ground-based NDVI system: A potential approach to improve satellite data interpretation. Remote Sensing, 2, 990-1013. https://doi.org/10.3390/rs2040990

Barnes, M. L., Moran, M. S., Scott, R. L., Kolb, T. E., Ponce-Campos, G. E., Moore, D. J. P., Ross, M. A., Mitra, B. B., \& Dore, S. (2016). Vegetation productivity responds to sub-annual climate conditions across semiarid biomes. Ecosphere, 7, e01339. https://doi.org/10.1002/ecs2.1339

Bell, J. E., Sherry, R., \& Luo, Y. (2010). Changes in soil water dynamics due to variation in precipitation and temperature: An ecohydrological analysis in tallgrass prairie. Water Resources Research, (46). https://doi.org/10.1029/2009WR007908

Bradford, J. B., Schlaepfer, D. R., Lauenroth, W. K., \& Palmquist, K. A. (2020). Robust ecological drought projections for drylands in the 21st century. Global Change Biology, 26, 3906-3919. https://doi.org/10.1111/gcb.15075

Breshears, D. D., Cobb, N. S., Rich, P. M., Price, K. P., Allen, C. D., Balice, R. G., Romme, W. H., Kastens, J. H., Floyd, M. L., Belnap, J., Anderson, J. J., Myers, O. B., \& Meyer, C. W. (2005). Regional vegetation die-off in response to global-change-type drought. PNAS, 102, 15144-15148. https://doi.org/10.1073/pnas.0505734102

Breshears, D. D., Myers, O. B., Meyer, C. W., Barnes, F. J., Zou, C. B., Allen, C. D., McDowell, N. G., \& Pockman, W. T. (2009). Tree die-off in response to global change-type drought: Mortality insights from a decade of plant water potential measurements. Frontiers in Ecology and the Environment, 7, 185-189. https://doi.org/10.1890/080016

Bunting, E. L. Munson, S. M., \& Villarreal, M. L. (2017). Climate legacy and lag effects on dryland plant communities in the southwestern U.S. Ecological Indicators, 74, 216-229. https://doi.org/10.1016/j.ecolind.2016.10.024 
Chapin, F. S. III, Schulze, E., \& Mooney, H. A. (1990). The ecology and economics of storage in plants. Annu Rev Ecol Syst, 21, 423-447. https://doi.org/10.1146/annurev.es.21.110190.002231

Clow, D. W. (2010). Changes in the timing of snowmelt and streamflow in Colorado: A response to recent warming. J. of Climate, 23, 2293-2306. https://doi.org/10.1175/2009JCLI2951.1

Coates, P., Prochazka, B. M., Ricca, K., Ben Gustafson, P., Ziegler, P., \& Casazza, M. (2017). Pinyon and Juniper Encroachment into Sagebrush Ecosystems Impacts Distribution and Survival of Greater Sage-Grouse. Rangeland Ecology \& Management, 70, 25-38. https://doi.org/10.1016/j.rama.2016.09.001

Devitt, D. A., Fenstermaker, L. F., Young, M. H., Conrad, B., Baghzouz, M., \& Bird, B. M. (2010). Evapotranspiration of mixed shrub communities in phreatophytic zones of the Great Basin region of Nevada (USA). J. Ecohydrology. https://doi.org/10.1002/eco.169

Devitt, D. A., Morris, R. L., \& Fenstermaker, L. K. (2005). Foliar damage, spectral reflectance and tissue ion concentrations of trees sprinkle irrigated with waters of similar salinity but different chemical composition. HortScience, 40(3), 819-826. https://doi.org/10.21273/HORTSCI.40.3.819

Devitt, D., Bird, B., Lyles, B., Fenstermaker, L., Jasoni, R., Strachan, S., Arnone, J., Biondi, F., Mensing, S., \& Saito, L. (2018). Assessing near surface hydrologic processes and plant response over a $1600 \mathrm{~m}$ mountain valley gradient in the Great Basin, NV, USA. Water, 10(4). https://doi.org/10.3390/w10040420

Eyre, F. H. (1980). Forest Cover Types of the United States and Canada. Society of American Foresters, Bethesda, MD.

Fenstermaker-Shaulis, L. K., Leskys, A., \& Devitt, D. A. (1997). Utilization of remotely sensed data to monitor a turfgrass irrigation study. J. Turfgrass Management, 2, 65-81. https://doi.org/10.1300/J099v02n01_06

Filippa, G., Cremonese, E., Migliavacca, M., Galvagno, M., Sonnentag, O., Humphreys, E., Hufkens, K., Rye, Y., Verfaillieand, J., \& diCella, U. M. (2018). NDVI derived from near-infrared -enabled digital cameras: Applicability across different plant functional types. Agric. For. Meteorol, 249, 275-285. https://doi.org/10.1016/j.agrformet.2017.11.003

Flake, S. W., \& Weisberg, P. J. (2019). Fine-scale stand structure mediates drought-induced tree mortality in pinyon-juniper woodlands. Ecological Applications, 29, 10.1002/eap.1831. https://doi.org/10.1002/eap.1831

Flanagan, L., Ehleringer, J., \& Marshall, J. (1992). Differential uptake of summer precipitation among co-occurring trees and shrubs in a pinyon-juniper woodland. Plant Cell and Environment, 15, 831-836. https://doi.org/10.1111/j.1365-3040.1992.tb02150.x

Floyd, M. L., Hanna, D. D., \& Romme, W. H. (2004). Historical and recent fire regimes in Pinon Juniper woodlands on Mesa Verde, Colorado USA. Forest Ecology and Management, 198, 269-289. https://doi.org/10.1016/j.foreco.2004.04.006

Grime, J. P., \& Campbell, B. D. (1991). Growth rate, habitat productivity and stress response. In H. A. Monney, E. J. Pel, \& W. E. Winner (Eds.), Response of Plant to Multiple Stresses (pp. 143-159). Academic Press, New York. https://doi.org/10.1016/B978-0-08-092483-0.50012-8

Hernandez-Clemente, R., Navarro-Cerrillo, R. M., Suarez, L., Morales, F., \& Zarco-Tejada, P. J. (2011). Assessing structural effects on PRI for stress detection in conifer forests. Remote Sensing of Environment, 115, 2360-2375. https://doi.org/10.1016/j.rse.2011.04.036

Hudson, P., Limousin, J., Krofcheck, D., Boutz, A., Pangle, R., Gehres, N., McDowell, N., \& Pockman, W. (2018). Impacts of long-term precipitation manipulation on hydraulic architecture and xylem anatomy of pinon and juniper in Southwest USA. Plant Cell and Environment, 41, 421-435. https://doi.org/10.1111/pce.13109

Huete, A. R. (1988). A soil-adjusted vegetation index (SAVI). Remote Sensing of Environment, 25, 295-309. https://doi.org/10.1016/0034-4257(88)90106-X

Huntington, J., Hegewisch, K., Daudert, B., Morton, C., Abatzoglou, J., McEvoy, D., \& Erickson, T. (2017). Climate Engine: Cloud Computing of Climate and Remote Sensing Data for Advanced Natural Resource Monitoring and Process Understanding. Bulletin of the American Meteorological Society. Retrieved from http://journals.ametsoc.org/doi/abs/10.1175/BAMS-D-15-00324.1;

https://doi.org/10.1175/BAMS-D-15-00324.1

IPCC. (2013). IPCC publishes full report climate change 2013: The Physical Science Basis. Fifth Assessment Report. Working Group 1. 
IPCC. (2014). Climate change 2014: Synthesis report. In R. K. Pachauri \& L. A. Meyer (Eds.), Contribution of Working Group l, ll, and lll to the fifth Assessment Report of the Intergovernmental Panel on Climate Change. Core Writing Team. IPCC, Geneva, Switzerland.

Jones, S. M., \& Gutzler, D. S. (2016). Spatial and Seasonal Variations in Aridification across Southwest North America. Journal of Climate, 29, 4637-4649. https://doi.org/10.1175/JCLI-D-14-00852.1

Karl, T. R. (2009). Global Climate Change Impacts in the United States. Cambridge University Press.

Kaye, M. W., \& Wagner, R. J. (2014). Eastern deciduous tree seedlings advance spring phenology in response to experimental warming, but not wetting, treatments. Plant Ecology, 215, 543-554. https://doi.org/10.1007/s11258-014-0322-2

Koehn, C. R., Petrie, M. D., Bradford, J. B., Litvak, M. E., \& Strachan, S. (2020). Seasonal precipitation and soil moisture relationships across forests and woodlands in the southwestern United States. Journal of Geophysical Research - Biogeosciences (in press). https://doi.org/10.1029/2020JG005986

Kozlowski, T. T., Kramer, P. J., \& Pallardy, S. G. (1991). The Physiological Ecology of Woody Plants. Academic Press, San Diego, CA. https://doi.org/10.1093/treephys/8.2.213

Krofcheck, D. J., Eitel, J. U. H., Lippitt, C. D., Vierling, L. A., Schulthess, U., \& Litvak, M. E. (2015). Remote sensing based simple models of GPP in both disturbed and undisturbed pinon-juniper woodlands in the Southwest U.S. Remote Sens, 8(1), 20. https://doi.org/10.3390/rs8010020

Krofcheck, D. J., Eitel, J. U. H., Vierling, L. A., Schulthess, U., Dettweiler-Robinson, E., Pendleton, R., \& Litvak, M. E. (2014). Linking structural with functional changes in a piñon-juniper woodland using a time series of high spatial resolution satellite data and eddy covariance. Remote Sensing of the Environment, Remote Sensing of Environment, 151, 102-113. https://doi.org/10.1016/j.rse.2013.11.009

Landhäusser, S. M., Pinno, B. D., Lieffers, V. J., \& Chow, P. S., (2012). Partitioning of carbon allocation to reserves or growth determines future performance of aspen seedlings. For Ecol Manage, 275, $43-51$. https://doi.org/10.1016/j.foreco.2012.03.010

Maelstrom, C. M., Thompson, M. V., Juday, G. P., Los, S. O., Randerson, J. T., \& Field, C. B. (1997). Interannual variation in global scale net primary production: Testing model estimates. Global Biogeochemical Cycles LL, 367-392. https://doi.org/10.1029/97GB01419

Mensing, S., Strachan, S., Arnone, J., Fenstermaker, L., Biondi, F., Devitt, D., Johnson, B., Bird, B., \& Fritzinger, E. (2013). A network for observing Great Basin Climate Change. EOS, Transactions For American Geophysical Union, 94(11), 105-106. https://doi.org/10.1002/2013E0110001

Morillas, L., Pangle, R., Maurer, G., Pockman, W., McDowell, N., Huang, C., Krofcheck, D., Fox, A., Sinsabaugh, R., Rahn, T., \& Litvak, M. (2017). Tree Mortality Decreases Water Availability and Ecosystem Resilience to Drought in Pinon-juniper Woodlands in the Southwestern US. Journal of Geophysical Research-Biogeosciences, 122, 3343-3361. https://doi.org/10.1002/2017JG004095

Mulla, D. J. (2012). Modeling and mapping soil spatial and temporatl variability. Hydropedology, 637-664. https://doi.org/10.1016/B978-0-12-386941-8.00020-4

Nicholson, S. E., \& Farrar, T. J. (1994). The influence of soil type on the relationships between NDVI, rainfall, and soil moisture in semi-arid Botswana. Part I. Relationship to rainfall. Remote Sens. Environ, 50, 107-120. https://doi.org/10.1016/0034-4257(94)90038-8

NOAA. (2021). El Nino and La Nina years and intensities. Retrieved from http://Ggweather.com/enso/oni.htm.

Nogues-Bravo, D., Araujo, M. B., Errea, M. P., \& Martinez-Rica, J. P. (2007). Exposure of global mountain systems to climate warming during the 21st century. Global Environmental Change, 17, $420-428$. https://doi.org/10.1016/j.gloenvcha.2006.11.007

Park, H., Jeong, S., Ho, C., Kim, J., Brown, M. E., \& Schaepman, M. E. (2015). Nonlinear response of vegetation green-up to local temperature variations in temperate and boreal forests in the northern hemisphere. Remote Sensing of Environment, 165, 100-108. https://doi.org/10.1016/j.rse.2015.04.030

Peek, M. S., Leffler, A. J., Hipps, L., Ivans, S., Ryel, R. J., \& Caldwell, M. M. (2006). Root turnover and relocation in the soil profile in response to seasonal soil water variation in a natural stand of Utah juniper (Juniperus osteosperma). Tree Physiology, 26, 1469-1476. https://doi.org/10.1093/treephys/26.11.1469 
Petrie, M. D., Pockman, W. T., Pangle, R. E., Limousin, J. M., Plaut, J. A., \& McDowell, N. G. (2015). Winter climate change promotes altered spring growing season in pinyon pine-juniper woodlands. Agricultural and Forest Meteorology, 214, 357-368. https://doi.org/10.1016/j.agrformet.2015.08.269

Pettorelli, N., Vik, J. O., Mysterud, A., Gaillard, J. M., Tucker, C. J., \& Stenseth, N. C. (2005). Using the satellite-derived NDVI to assess ecological responses to environmental change. Trends in Ecology and Evolution, 20, 503-510. https://doi.org/10.1016/j.tree.2005.05.011

Plaut, J., Wadsworth, W., Pangle, R., Yepez, E., McDowell, N., \& Pockman, W. (2013). Reduced transpiration response to precipitation pulses precedes mortality in a pinon-juniper woodland subject to prolonged drought. New Phytologist, 200, 375-387. https://doi.org/10.1111/nph.12392

Price, K. P. (1993). Detection of soil-erosion within pinyon-juniper woodlands using thematic mapper (tm) data. Remote Sensing of Environment, 45, 233-248. https://doi.org/10.1016/0034-4257(93)90107-9

Qi, J., Chehbouni, A., Huete, A. R., Kerr, Y. H., \& Sorooshian, S. (1994). A modified soil adjusted vegetation index. Remotes Sensing of Environment, 48, 119-126. https://doi.org/10.1016/0034-4257(94)90134-1

Rasmussen, R., Ikeda, K., Liu, C., Gochis, D., Clark, M., Dai, A., Gutmann, E., Duhia, J., Chen, F., Barlage, M., Yates, D., \& Zhang, G. (2014). Climate change impacts on the water balance of the Colorado headwaters: high resolution regional climate model simulations. J. Hydrometeorology, 15(3), 1091-1116. https://doi.org/10.1175/JHM-D-13-0118.1

Rautiainen, M., Lukes, P., Homolova, L., Hovi, A., Pisek, J., \& Mottus, M. (2018). Spectral properties of coniferous forests: A review of in situ and laboratory measurements. Remote Sensing, 10, 207. https://doi.org/10.3390/rs10020207

Reed, P. B., Pfeifer-Meister, L. E., Roy, B. A., Johnson, B. R., Bailes, G. T., Nelson, A. A., Boulay, M. C., Hamman, S. T., \& Bridgham, S. D. (2019). Prairie plant phenology driven more by temperature than moisture in climate manipulations across a latitudinal gradient in the Pacific Northwest, USA. Ecology and Evolution, 9, 3637-3650. https://doi.org/10.1002/ece3.4995

Rodriguez-Iturbe, I. (2000). Ecohydrology: A hydrologic perspective of climate-soil-vegetation dynamics. Water Resources Research, 36, 3-9. https://doi.org/10.1029/1999WR900210

Sala, O. E., Gherardi, L. A., Reichmann, L., Jobbagy, E., \& Peters, D. (2012). Legacies of precipitation fluctuations on primary production: Theory and data synthesis. Philos. Trans. R. Soc. Lond. B: Biol. Sci., 367(1606), 3135-3144. https://doi.org/10.1098/rstb.2011.0347

Scanlon, B. R., Levitt, D. G., Reedy, R. C., Keese, K. E., \& Sully, M. J. (2005). Ecological controls on water-cycle response to climate variability in deserts. PNAS, 102, 6033-6038. https://doi.org/10.1073/pnas.0408571102

Seager et al. (2007). Model projections of an imminent transition to a more arid climate in southwestern North America. Science, 316, 1181-1184. https://doi.org/10.1126/science.1139601

Shaw, J. D., Steed, B. E., \& Deblander, L. T. (2005). Forest inventory and analysis (FIA) annual inventory answers the question: What is happening to pinyon juniper woodlands? Journal of Forestry, 103(6), 280-285.

Snyder, K. A., Huntington, J. L., Wehan, B. L., Morton, C. G., \& Stringham, T. K. (2019). Comparison of Landsat and land -based phenology camera normalized difference vegetation index (NDVI) for dominant plant communities in the Great basin. Sensors, 19, 1139. https://doi.org/10.3390/s19051139

Trenberth, K. D., Dai, A., Rasmussen, R. M., \& Parsons, D. B. (2003). The changing character of precipitation. Bull, Amer. Meteor. Soc., 84, 1205-1217. https://doi.org/10.1175/BAMS-84-9-1205

Truettner, C., Dettinger, M. D., Ziaco, E., \& Biondi, F. (2019). Seasonal analysis of the 2011-2017 North American monsoons near its northwest boundary. Atmosphere, 10, 420. https://doi.org/10.3390/atmos10070420

USDA USFS Pinus edulis. Fs.fed.us/database/feis/plants/tree/pinedu/all.html. Accessed December 2020.

USU Tree Browser. https://treebrowser.org/. Accessed December 2020.

Wang, J., Price, K. P., \& Rich, P. M. (2001). Spatial patterns of NDVI in response to precipitation and temperature in the central Great Plains. Int. J. Remote Sensing, 22, 3827-3844. https://doi.org/10.1080/01431160010007033 
Wang, J., Rich, P. M., \& Price, K. P. (2003). Temporal responses of NDVI to precipitation and temperature in the central Great Plains, USA. Int. J. of Remote Sensing, 24(11), 2345-2364. https://doi.org/10.1080/01431160210154812

Weisberg, P. J., Lingua, E., \& Pillai, R. B. (2007). Spatial patterns of pinyon-juniper woodland expansion in. central Nevada. Rangeland Ecology \& Management, 60, 115-124. https://doi.org/10.2111/05-224R2.1

West, A., Hultine, K., Burtch, K., \& Ehleringer, J. (2007). Seasonal variations in moisture use in a pinon-juniper woodland. Oecologia, 153, 787-798. https://doi.org/10.1007/s00442-007-0777-0

Wolkovich et al. (2012). Warming experiments underpredict plant phenological responses to climate change. Nature, 485, 494-497. https://doi.org/10.1038/nature11014

Wuebbles, D. J., Fahey, D. W., Hibbard, K. A., DeAngelo, B., Doherty, S., Hayhoe, K., Horton, R., Kossin, J. P., Taylor, P. C., Waple, A. M., \& Weaver, C. P. (2017). Executive summary. In D. J. Wuebbles, D. W. Fahey, K. A. Hibbard, D. J. Dokken, B. C. Stewart, \& T. K. Maycock (Eds.), Climate Science Special Report: Fourth National Climate Assessment (Vol. I, pp. 12-34). U.S. Global Change Research Program, Washington, DC, USA. https://doi.org/10.7930/J0DJ5CTG

Xu, X., Riley, W. J., Koven, C. D., \& Jia, G. (2019). Heterogeneous spring phenology shifts affected by climate: Supportive evidence from two remotely sensed vegetation indices. Environ. Res. Commun. https://doi.org/10.1088/2515-7620/ab3d79

Zhang, S., Fridel, M. A., Schaaf, C. B., \& Strahler, A. H. (2005). Monitoring the response of vegetation phenology to precipitation in Africa by coupling MODIS and TRMM instruments. Journal of Geophysical Research, 110, D12103. https://doi.org/10.1029/2004JD005263

\section{Copyrights}

Copyright for this article is retained by the author(s), with first publication rights granted to the journal.

This is an open-access article distributed under the terms and conditions of the Creative Commons Attribution license (http://creativecommons.org/licenses/by/4.0/). 